\title{
A Systematic Review of Intuition-A Way of Knowing in Clinical Nursing?
}

\author{
Anne Lise Holm ${ }^{*}$, Elisabeth Severinsson ${ }^{2}$ \\ ${ }^{1}$ Department of Health Science, Stord/Haugesund University College, Stord, Norway \\ ${ }^{2}$ Centre for Women's, Family and Child Health, Faculty of Health Sciences, University College of Southeast \\ Norway, Kongsberg, Norway \\ Email: *anne.holm@hsh.no
}

Received 1 April 2016; accepted 24 May 2016; published 27 May 2016

Copyright $@ 2016$ by authors and Scientific Research Publishing Inc.

This work is licensed under the Creative Commons Attribution International License (CC BY). http://creativecommons.org/licenses/by/4.0/

(c) $\underset{\mathrm{EY}}{\mathrm{EY}}$ Open Access

\section{Abstract}

The aim of this systematic review was to illuminate intuition in clinical nursing. Frequently described as a defining characteristic of professional expertise, intuition is gaining acceptance as a legitimate form of knowledge in clinical nursing. A total of 352 abstracts were read and eight quantitative studies included. A thematic analysis was performed to one main theme, two themes, and four sub-themes emerged. The main theme was: Sensing an unconscious and conscious state of mind, and the two themes were: A sudden emotional awareness and reflection, and arousal of conscious thought processes. The first theme included two sub-themes: Sensing spiritual connections with patients and experiencing physical sensations; worrying and reassuring feelings. The second theme comprised two sub-themes: Willingness to act on personal, interpersonal, and clinical experiences; the influence of maturity and social support in clinical decision-making. An implication for clinical nursing was the need to develop sensitivity as a key to understanding the patient's illness. In conclusion, leadership and management could facilitate discussions about intuition as a legitimate method of processing information and making decisions about patient care.

\section{Keywords}

Clinical Nursing, Conscious, Emotional Awareness, Knowledge, Unconscious

\section{Introduction}

Intuition has been described as emotional awareness [1]. The emotional center of the brain (amygdala) plays a key role in emotional interpretation, where synapses respond emotionally to all exogenous stimuli [2]. In this

"Corresponding author. 
way, the amygdala can indirectly retrigger emotions and a behavioral response to stimuli that have been experienced in the past, but are dormant in the unconscious [3]. The duration of this interface between emotional response and reasoning has been described as milliseconds. According to Panksepp [4], it results in human beings feeling before they think, which is essential when describing intuition and emotional awareness. Shirley and Langan-Fox [5] distinguish between intuition and insight by arguing that intuition does not involve conscious awareness, while insight is the awareness of something based on rational thinking. A further distinction is that insight contains solutions to a known problem, while intuition appears to be a non-specific way of relating to a person or situation [6]. A consequence seems to be that the brain and heart receive, process, and decode intuitive information. Significant gender differences have been found, indicating that women are more attuned than men to the intuitive information provided by the heart [7] [8]. The absence of a consensus on the definition of intuition is highlighted by Appleton and Cowley [9].

Theoretical studies have focused on neural scientific perspectives of intuitive practice in nursing [10]. According to McKinnon [10], neural scientific perspectives are important for clarifying the ambiguity associated with intuition and redefine it as a working concept. Intuition in nursing is originally identified by Carper [11], who presents four fundamental patterns of knowing: 1) Empirical knowledge, which is factual knowledge from science or other external sources that can be verified empirically; 2) Personal knowledge, which comprises knowledge and attitudes derived from personal self-understanding and empathy, including imagining the self in the patient's position; 3) Ethical knowledge, involving attitudes and knowledge derived from an ethical framework, including an awareness of moral questions and choices; 4) Aesthetic knowledge, defined as awareness of the current situation based in immediate practical action, including a view of the patient and her/his circumstances as uniquely individual, and of the wholeness of the situation. Carper [11] emphasizes attitudes, intuition, and actions as equally integral to nursing care. Benner and Tanner ([12], p. 23) define intuition as "understanding without a rationale”. King and Appleton [13] traced the intuitive grasp of the expert by critically reviewing articles published between 1983 and 1996. They conclude that intuition is a valid component of nursing judgment and practice based on the evidence from research. Intuition has been described as a defining characteristic of professional expertise and is gaining acceptance as a legitimate form of knowledge in clinical nursing [14]. Although a universal definition of the construct does not exist, Charter ([14], p. 130) states that most descriptions of intuition include "rapid perception, lack of awareness of the processes engaged, concomitant presence of emotions and holistic understanding of the problem situation". These authors propose a new theory that emphasizes how perception and conscious problem solving are intimately related [14].

A systematic review of the state of the science of intuition in nursing Rew and Barrow [15] reveals that most studies are descriptive with an exploratory design and that nurses affirm that intuition is salient to expertise in clinical practice and should be carefully taught to students and novice nurses. Intuition is rejected by many as being irrelevant to nurses' decision-making process. However, research also validates intuitive knowledge in sound decision-making among nurses [16]. Four qualitative studies have explored intuition in nursing practice [17]-[20]. Ruth-Sahd and Tisdell [17] revealed that novice nurses were influenced by experience and that connections were central to the development of meaning through intuition. Time, space, and touch proved to be significant for facilitating intuition. Lyneham et al. [18] explored the experience of knowing in emergency nursing practice and found concepts such as; knowledge, experience, connection, feeling, syncretism, and trust. Traynor et al. [19] examined how nurses defined professional clinical decision-making processes. The participants highlighted their personal "experience" as the final arbiter of decision-making [19]. Olsson and Adolfsson [20] demonstrated that when nurses used the reasoning strategy of hypothesis testing, they considered all criteria, including the patients' risk-benefits, organizational necessities, and complementary sources of information. The concept of intuition has been variously used in the nursing literature for studying a range of settings and outlining theoretical understanding.

\section{Aim and Review Question}

The aim of this systematic review was to illuminate intuition in clinical nursing. The review question was: What is described as intuition in clinical nursing?

\section{Methods}

A systematic review method [21] was used in order to critically appraise the quality of the available evidence. A 
systematic review comprises a clearly stated set of objectives with an explicit reproducible methodology; a systematic search that attempts to identify all studies that meet the eligibility criteria; an assessment of the validity of the findings of the included studies; and a systematic presentation and synthesis of the characteristics and findings of the included studies ([22], p.55). The systematic review method enables a rigorous synthesis of the included studies and adheres to the preferred reporting items for systematic reviews, PRISMA and meta-analyses [22].

\subsection{Inclusion and Exclusion Criteria}

The inclusion criteria were full-text studies comprising empirical nursing research based on quantitative or mixed method approaches, published in the English language, and with intuition in the title. The decision to make the title an inclusion criterion was to ensure that intuition and nursing were the main concepts explored, described or studied. Exclusion criteria were qualitative research and theoretical articles.

\subsection{Literature Search}

The literature search aimed to identify full-text articles with the word intuition in the title. The search methodologies employed can enhance the validity of a systematic review [23]. A literature search was performed in the Academic Search Elite (EBSCOhost), ProQuest, PubMed, and Cinahl databases for the period 2004 to 2015 (Figure 1). The keywords used were: intuition and nursing, and the search resulted in a total of 352 abstracts.

\subsection{Quality Assessment}

The quality of the eight included papers was reviewed, evaluated, and reflected on by the two authors (ALH, ES), with focus on design, sample size, measurements, statistical analysis, generalizability, reliability (Table 1), as well as ethical approval, demographic characteristics, and limitations.

The main results of the study by Cork [24] revealed an average of more than 10 years of experience as an ED registered nurse, the Yes and No responses to the question about certification were equal, and highest level of education was BNS. Phase II consisted of a review of 393 eligible medical records, of which 33 were excluded, leaving a total of 360 with 109 in the 'gut instinct' and 251 in the "other" category. Pearson's $r$ correlation coefficient was calculated to determine the relationship between the 2 variables. The results indicated a strong positive correlation $(r=0.992$; $\mathrm{p}<0.001)$. Farr-Wharton et al. [25] confirmed the impact of supervisor-nurse relationships on the use of intuition in all three generations. The findings add new knowledge about the differing im-

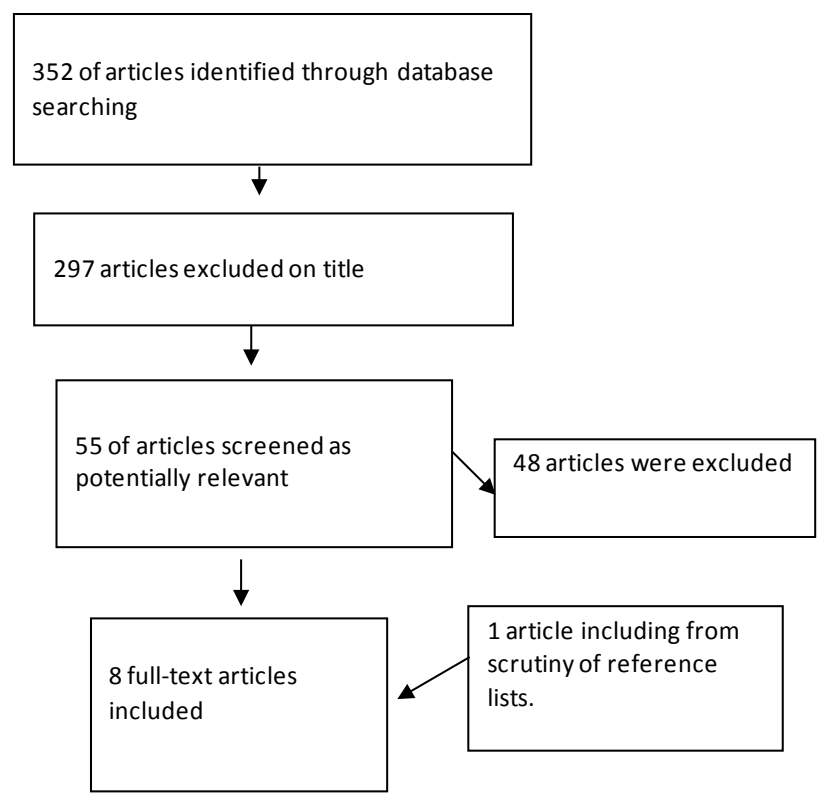

Figure 1. Flow chart of search and retrieval process. 
portance of intuition for Generation X, Generation Y and Baby Boomer nurses' perceptions of empowerment, suggesting it is more important to Baby Boomers and Generation X than to Generation Y. The impact of using intuition differed significantly among the generational cohorts. Pretz and Folse [26] identified two independent aspects of nursing intuition uniquely related to general intuition and nursing experience.

Preference for intuition in nursing was not due to a general preference for intuition, but use of nursing intuition increased with experience. In the study by Rovithis et al. [27] the overall intuition score of the nursing staff was 53.2 (mean levels). No statistically significant differences associated with specialty or work experience ( $p>$ 0.05 ) were observed in the intuition levels of the nursing staff. However, the categories into which the questionnaire is divided showed a positive correlation between them ( $p$ value $>0.001)$. Ruth-Sahd and Hendy [28] revealed that novice nurses were more likely to use intuition to guide patient care if they were older, had been hospitalized themselves, and experienced more social support. Smith et al. [29] presented seven factors accounting for $66.2 \%$ of the variance: physical sensations (28.4\%); premonitions (9.7\%); spiritual connections (7.7\%); reading of cues (6.1\%); sensing energy (5.7\%); apprehension (4.3\%); and reassuring feelings (4\%).

The validation resulted in a revised 25-item measure that demonstrated an overall Cronbach's alpha of 0.89 and a range of $0.69-0.84$ for each factor. Smith's [30] results led to a 26-item intuition instrument with 6 factors accounting for $62 \%$ of the variance. The factors were labelled Feelings that reassure (27.7\%), Spiritual connections (19.9\%), Feelings that alert (8.4\%), Feelings that forewarn (5.8\%), Physical sensations that alert (4.7\%), and Reading physical cues (4.2\%). Eigenvalues ranged from 1.100 to 7.225, and Factor loadings from 0.572 to 0.848 .

The overall Cronbach's alpha was 0.89 with a range of 0.73 to 0.85 for each factor. Smith [31] described their findings as preliminary and the principal component factor analysis resulted in four factors accounting for $70.8 \%$ of variance: Spiritual connections (37.3\%), Reassuring feelings (14.6\%), Physical sensations (12.5\%) and Bad feelings (6.2\%). Eigenvalues ranged from 1.1 to 6.7 and factor loadings from 0.705 to 0.887 . Pearson's Correlation between the two intuition measures was 0.520 .

In three studies the design was described as cross-sectional [24] [25] [30], while one study was a survey [26]. Four of the studies contained no information about the design [27]-[29] [31]. The sample size of the studies ranged from 8 to 2500 persons. Two studies lacked information about the mean age [24] [25]. Five studies had a response rate of between 7.9\% and 75\% [24]-[29] [30] (Table 2). Three studies provided no information about the response rate [26] [27] [31]. The validity and reliability of the measurements used are presented in Table 1. There was no mention of the validity or reliability of the CNQ instrument in one study [24]. All of the included studies contained statistical analyses (Table 1 ). In one study problems with generalizing the findings were mentioned [24].

All of the included studies contained some demographic data (Table 2). Three studies were approved by an institution, hospital and/or university review board [25] [27] [30]. Five studies included no information about ethical approval [24] [26]-[29] [31].

\subsection{Thematic Analysis}

The present review used thematic analysis to produce a synthesis for identifying, grouping, and summarizing findings, as described by [32]. The thematic analysis was performed by A.L.H.

The synthesis comprised quantitative data, from which the themes emerged in the course of the analysis process. The themes were identified by reading and re-reading the studies in order to synthesize the findings [33]. In a thematic synthesis it is necessary to find words that describe the text. By means of words and text the present authors identified different patterns and concepts in the data. This process resulted in common meanings that can be considered descriptions of the use of intuition in nursing practice. The authors discussed the themes and subthemes several times before finally reaching consensus on the labeling (Table 3). However, a thematic analysis can have some important limitations when exploring data [32]. In order to ensure trustworthiness, the authors attempted to avoid focusing on one study at the expense of another, as recommended by Pope et al. [32].

\section{Results}

The thematic analysis revealed one main theme: Sensing an unconscious and conscious state of mind, and two themes: A sudden emotional awareness and reflection, and arousal of conscious thought processes. Two subthemes emerged in the first theme: Sensing spiritual connections with patients and experiencing physical sensa- 
Table 1. Summary of intuition in nursing research and practice.

\begin{tabular}{|c|c|c|c|c|c|}
\hline $\begin{array}{c}\text { Author } \\
\text { Year, Country }\end{array}$ & Aim & $\begin{array}{l}\text { Sample } \\
\text { Size }\end{array}$ & $\begin{array}{c}\text { Design } \\
\text { Measurements }\end{array}$ & $\begin{array}{l}\text { Statistical } \\
\text { Analysis }\end{array}$ & Limitations \\
\hline $\begin{array}{l}\text { 1. Cork } \\
\text { (2014) } \\
\text { USA }\end{array}$ & $\begin{array}{l}\text { To explore the validity of } \\
\text { nurses' use of intuition when } \\
\text { predicting the severity of } \\
\text { patients' injuries, and } \\
\text { whether it impacts on their } \\
\text { decision to institute a trauma } \\
\text { code }\end{array}$ & $\begin{array}{c}\mathrm{N}=8 \text { nurses } \\
\begin{array}{l}\mathrm{N}=360 \\
\text { records }\end{array}\end{array}$ & $\begin{array}{c}\text { Quantitative } \\
\text { Descriptive } \\
\text { Cross-sectional } \\
\text { CNQ }\end{array}$ & Cohort analysis & $\begin{array}{l}\text { Small sample size from one } \\
\text { hospital. } \\
\text { Short questionnaire and the } \\
\text { subjective nature of nurses } \\
\text { who used intuition. } \\
\text { The number of records } \\
\text { analyzed was } 360 \text {. These } \\
\text { factors might affect the } \\
\text { generalizability of this study. }\end{array}$ \\
\hline $\begin{array}{l}2 . \\
\text { Farr-Wharton } \\
\text { et al. }(2011) \\
\text { AUSTRALIA }\end{array}$ & $\begin{array}{l}\text { To examine the influence of } \\
\text { the supervisor-subordinate } \\
\text { relationship on three } \\
\text { generational nurse cohorts' } \\
\text { use of intuition, perceptions } \\
\text { of empowerment, and } \\
\text { affective commitment. }\end{array}$ & $N=2500$ & $\begin{array}{l}\text { Quantitative } \\
\text { Cross-sectional } \\
\text { LMX-7, AC } \\
\text { Self-report } \\
\text { Survey }\end{array}$ & $\begin{array}{l}\text { Correlations, } \\
\text { regression } \\
\text { analysis, and } \\
\text { MANOVAS- } \\
\text { path analysis }\end{array}$ & $\begin{array}{l}\text { The measurements used were } \\
\text { previously validated, except } \\
\text { for the measure for intuition, } \\
\text { which comprised three items. } \\
\text { The Cronbach's Alpha scores } \\
\text { for reliability were all within } \\
\text { acceptable limits. }\end{array}$ \\
\hline $\begin{array}{l}\text { 3. Pretz \& } \\
\text { Folse (2011) } \\
\text { USA }\end{array}$ & $\begin{array}{l}\text { To examine the relationship } \\
\text { between domain-specific and } \\
\text { domain-general intuition } \\
\text { among practicing nurses and } \\
\text { student nurses to determine } \\
\text { the role of intuition in } \\
\text { nurses' decision-making. }\end{array}$ & $\begin{array}{l}N=175 \\
N=145 \\
N=30\end{array}$ & $\begin{array}{l}\text { Quantitative } \\
\text { Survey } \\
\text { Correlational } \\
\text { Design } \\
\text { REI, MBTI, } \\
\text { TIntS, MII, } \\
\text { AUINS, SII. }\end{array}$ & $\begin{array}{l}\text { Quantitative } \\
\text { analysis. } \\
\text { Descriptive and } \\
\text { inferential } \\
\text { statistics }\end{array}$ & $\begin{array}{l}\text { Because the measurement } \\
\text { (TIntS) was the only } \\
\text { subscale that demonstrated } \\
\text { adequate reliability in the } \\
\text { sample, it was the only scale } \\
\text { included in the analysis. The } \\
\text { measures were self-report in } \\
\text { nature and do not necessarily } \\
\text { reflect intuition in } \\
\text { decision-making. }\end{array}$ \\
\hline $\begin{array}{l}\text { 4.Rovithis et } \\
\text { al. (2015) } \\
\text { GREECE }\end{array}$ & $\begin{array}{l}\text { To describe and compare the } \\
\text { intuition levels in } \\
\text { nursing staff working in the } \\
\text { Emergency Department, the } \\
\text { Intensive Care Unit and in } \\
\text { surgical wards }\end{array}$ & $\mathrm{N}=122$ & $\begin{array}{l}\text { Quantitative } \\
\text { SII }\end{array}$ & $\begin{array}{l}\text { Correlation } \\
\text { analysis }\end{array}$ & $\begin{array}{l}\text { The reliability of the } \\
\text { measurement assessed by } \\
\text { Cronbach's Alpha was } \\
\text { described as overall } \\
\text { reliability. It is recommended } \\
\text { that the questionnaire should } \\
\text { be adjusted to the Greek } \\
\text { context and that a new } \\
\text { research instrument to } \\
\text { measure intuition should be } \\
\text { designed. }\end{array}$ \\
\hline $\begin{array}{l}\text { 5.Ruth-Sahd } \\
\text { \& Hendy } \\
\text { (2004) } \\
\text { USA }\end{array}$ & $\begin{array}{l}\text { To provide new } \\
\text { information about which } \\
\text { types of past experience are } \\
\text { the most powerful } \\
\text { predictors of novice nurses' } \\
\text { use of intuition. }\end{array}$ & $\mathrm{N}=323$ & $\begin{array}{l}\text { Quantitative } \\
\text { UI, PE, IE, PE. }\end{array}$ & $\begin{array}{l}\text { Descriptive } \\
\text { statistics. } \\
\text { Multiple } \\
\text { regression }\end{array}$ & $\begin{array}{l}\text { The need for a larger } \\
\text { sample in future studies. } \\
\text { The sample was dominated } \\
\text { by white women. }\end{array}$ \\
\hline $\begin{array}{l}\text { 6. Smith et al. } \\
\qquad \begin{array}{l}\text { (2004) } \\
\text { USA }\end{array}\end{array}$ & $\begin{array}{l}\text { To describe the development } \\
\text { and psychometric testing of } \\
\text { an instrument to measure use } \\
\text { of intuition by nursing } \\
\text { students. }\end{array}$ & $\mathrm{N}=349$ & $\begin{array}{l}\text { Quantitative IM } \\
\text { Psychometric } \\
\text { evaluation. } \\
\text { Self-report } \\
\text { survey }\end{array}$ & $\begin{array}{c}\text { Principal } \\
\text { component } \\
\text { factor analysis }\end{array}$ & $\begin{array}{l}\text { The construct validity of the } \\
\text { scale used for the } \\
\text { students showed construct } \\
\text { validity and reliability. }\end{array}$ \\
\hline $\begin{array}{l}\text { 7.Smith } \\
\text { (2006) } \\
\text { USA }\end{array}$ & $\begin{array}{l}\text { To evaluate the } \\
\text { psychometric properties of } \\
\text { the revised intuition } \\
\text { instrument containing } \\
\text { 32-items, and to clarify the } \\
\text { factors that resulted in the } \\
\text { first psychometric } \\
\text { evaluation. }\end{array}$ & $\mathrm{N}=326$ & $\begin{array}{l}\text { Quantitative } \\
\text { III } \\
\text { Psychometric } \\
\text { evaluation. }\end{array}$ & $\begin{array}{l}\text { Likert response } \\
\text { format. } \\
\text { Factor analysis }\end{array}$ & $\begin{array}{c}\text { The instrument showed } \\
\text { evidence of construct validity } \\
\text { and reliability. } \\
\text { A larger nationwide sample } \\
\text { would be ideal. } \\
\text { The use of other statistical } \\
\text { methods. }\end{array}$ \\
\hline
\end{tabular}


Continued

\begin{tabular}{|c|c|c|c|c|c|}
\hline $\begin{array}{l}\text { 8. Smith } \\
\text { (2007) } \\
\text { USA }\end{array}$ & $\begin{array}{l}\text { To administer the Smith } \\
\text { Intuition Instrument to a } \\
\text { sample of registered nurses } \\
\text { to clarify its factors and test } \\
\text { convergent validity. }\end{array}$ & $\mathrm{N}=79$ & $\begin{array}{c}\text { Quantitative } \\
\text { Cross-sectional. } \\
\text { SII, MII. }\end{array}$ & Factor analysis & $\begin{array}{l}\text { Psychometric evaluation } \\
\text { demonstrated construct } \\
\text { validity, convergent } \\
\text { validity and reliability. The } \\
\text { response rate in this study } \\
\text { was poor. }\end{array}$ \\
\hline
\end{tabular}

AC = Affective Commitment; AUINS = Acknowledges Use of Intuition in Nursing Scale. BB = Baby Boomer, CNQ = Charge Nurse Questionnaire IE = Interpersonal Experiences. III = Initial Intuition Instrument. IM = Intuition Measure. LMX-7 = Leader-Member Exchange. MII = Miller Intuitiveness Instrument. MBTI $=$ Myers Briggs Type Indicator. PE $=$ Personal Experiences. REI $=$ Rational Experimental Inventory. RSES = Rosenberg Self-Esteem Scale. SII = Smith's Intuition Instrument. SSFFS = Social Support from Family and Friends Scale. TIntS = Types of Intuition Scale. SII = Smith’s Intuition Instrument. UI = Use of Intuition. WAIS = Willingness to Act on Intuition Subscale.

tions, and worrying and reassuring feelings. The second theme had the following two sub-themes: Willingness to act on personal, interpersonal, and clinical experiences, and the influence of maturity and social support in clinical decision-making.

\subsection{Sensing an Unconscious and Conscious State of Mind}

The findings on intuition revealed a state of mind described as sensing a sort of energy in the unconscious part of the brain. Feelings and thoughts can be seen as working together, thus combining the emotional center and the conscious part of the brain. Feelings can be powerful catalysts for the rational choices made by human beings. Intuition can thus be viewed as combining the unconscious and conscious mind or as a feeling that emerges from the unconscious mind. Nurses seem to sense this emotional awareness as a more or less somatic state that produces a pleasant or an unpleasant feeling. This sort of physical and emotional awareness is experienced as a form of energy made up of physical sensations, as well as spiritual connectedness with patients. Thus, it seems reasonable to consider the part of the brain that coordinates emotions (amygdala).

When a sudden and life threatening event occurs, the nurse must immediately focus and reflect on it and be aware of this feeling, as failure to do so can have serious consequences for the patients.

\subsubsection{A Sudden Emotional Awareness and Reflection}

The results revealed that emotional awareness is often described as using nursing intuition [24] [26] [29]-[31]. Emotional awareness was defined as being embodied in three distinct sub-dimensions; premonitions, apprehension, and reassuring feelings [29]. The three dimensions of intuition were explained as; physical awareness, emotional awareness, and making connections [31]. Cork [24] reviewed 393 medical files where one record was called "gut instinct category", explained as intuition. To evaluate the linear relationship between the "gut instinct" data and the "other" data, Pearson's $r$ correlation coefficient was calculated to determine the magnitude and direction of the relationship between the two variables. The results indicated a very strong positive correlation between the sets of data $(r=0.992 ; p<0.001)$ [24].

1) Sensing Physical Sensations and Spiritual Connections with Patients

The results revealed that sensing energy loaded on the factor spiritual connections [29]. Nurses who develop relationships with patients and spend more time providing direct patient care might be better able to read the patients' cues and sense energy, while those who only briefly interact with patients may be more in tune with immediate physical and emotional feelings [29]. The results also described spiritual connections including verbal communication, a sense of the energy field, and deep relationships [30]. Experiences of nausea and shivers down the spine occurred when something was wrong with the patients [26] [30]. Trusting physical, spiritual or energy connections with patients was ascribed to a general ability for intuition and less to experience in the field. Nursing intuition was described as having two dimensions: 1) a sense of being skilled and able to read patients' cues; 2) an interest in innovation in practice. The analysis showed that domain-general intuition was independent of all nursing intuition measures. Nursing and general intuition measures were not strongly correlated and confirmed the hypothesis that intuition is domain-specific. Individuals who trust intuition in the nursing domain do not necessarily trust intuition in general [26].

2) Worrying and Reassuring Feelings

The results contained descriptions of having a bad feeling about a patient's condition [30]. Reassuring feel- 
Table 2. Demographic characteristics.

\begin{tabular}{|c|c|c|c|c|}
\hline $1^{\text {st }}$ author, year & Gender & Age, mean age, response rate & Education, expertise, years of experience & Ethnicity \\
\hline $\begin{array}{l}\text { 1. Cork (2014) } \\
\text { USA }\end{array}$ & Not reported. & $\begin{array}{l}\text { Age and mean age not } \\
\text { reported. } \\
\text { Response rate } 75 \% \text {. }\end{array}$ & $\begin{array}{l}\text { Advanced cardiac life support and trauma } \\
\text { nurse core curriculum certified. } \\
\text { RN } \\
4 \text { over } 16 \text { years } \\
1 \text { between } 6-10 \text { years } \\
1 \text { between } 11-15 \text { years } \\
\text { Emergency department nurse (ED) } \\
2 \text { over } 16 \text { years } \\
3 \text { between } 6-10 \text { years } \\
1 \text { between } 0-5 \text { years. }\end{array}$ & Not reported. \\
\hline $\begin{array}{l}\text { 2. Farr-Wharton } \\
\text { et al. (2011) } \\
\text { AUSTRALIA }\end{array}$ & $\begin{array}{l}96.33 \% \text { female. } \\
3.67 \% \text { male. }\end{array}$ & $\begin{array}{l}54.11 \% \text { over } 45 \text { years } \\
8 \%<30 \text { years. } \\
\text { Mean age not reported. } \\
36 \% \text { response rate. }\end{array}$ & $\begin{array}{l}55 \text { NUM position, } \\
111 \text { clinicians, } \\
516 \text { RNs } \\
213 \text { Enrolled Nurses } \\
5 \text { 'others'. } \\
107 \text { - under } 1 \text { year. } \\
260 \text { between } 1 \text { and } 5 \text { years, } 160 \text { between } 5 \\
\text { and } 10 \text { years, } 73 \text { between } 10 \text { and } 15 \text { years } \\
300 \text { more than } 15 \text { years. }\end{array}$ & Not reported. \\
\hline $\begin{array}{l}\text { 3. Pretz \& Folse } \\
\text { (2010) USA }\end{array}$ & $\begin{array}{l}78 \% \text { female RNs } \\
73 \% \text { female BSN }\end{array}$ & $\begin{array}{l}\text { Mean age RN } 38.71 \text { years. } \\
\text { Mean age BSN } 20.48 \text { years. } \\
\text { Response rate not reported. }\end{array}$ & $\begin{array}{l}64 \text { RNs. } \\
38 \text { medical/surgical nurses } \\
14 \text { critical care } \\
13 \text { maternal/newborn }\end{array}$ & Not reported. \\
\hline $\begin{array}{l}\text { 4. Rovithis et al. } \\
\text { (2015) GREECE }\end{array}$ & $\begin{array}{l}77.9 \% \text { female. } \\
22.1 \% \text { male. }\end{array}$ & $\begin{array}{l}\text { Mean age } 28.5 \text { years. } \\
\text { Response rate not reported. }\end{array}$ & $\begin{array}{l}91 \text { RNs. } \\
31 \text { ANs. } \\
29 \text { in emergency department, } 54 \text { in surgical } \\
\text { clinics, } 39 \text { in intensive care unit. } \\
24 \text { between } 1 \text { and } 4 \text { years. } \\
27 \text { between } 5 \text { and } 10 \text { years. } \\
20 \text { between } 11 \text { and } 15 \text { years. } \\
19 \text { between } 16 \text { and } 20 \text { years. } \\
22 \text { between } 21 \text { and } 25 \text { years. } \\
9 \text { over } 25 \text { years. }\end{array}$ & Not reported. \\
\hline $\begin{array}{l}\text { 5. Ruth-Sahd \& } \\
\text { Hendy (2004) } \\
\text { USA }\end{array}$ & $\begin{array}{l}91.0 \% \text { female. } \\
9 \% \text { male. }\end{array}$ & $\begin{array}{l}\text { Mean age } 27.5 \text { years. } \\
\text { Response rate } 23.2 \% \text { and } \\
27.6 \% \text {. }\end{array}$ & Novice nurses. & $\begin{array}{l}92 \% \text { white. } \\
2.2 \% \text { Afro-American. } \\
2.2 \% \text { Hispanic. } \\
2.2 \% \text { Asian. } \\
1.5 \% \text { 'other'. }\end{array}$ \\
\hline $\begin{array}{l}\text { 6. Smith et al. } \\
\text { (2004) USA }\end{array}$ & $\begin{array}{l}89.1 \% \text { female. } \\
10.9 \% \text { male. }\end{array}$ & $\begin{array}{l}\text { Mean age } 40.7 \text { years. } \\
\text { Response rate } 35 \% .\end{array}$ & $\begin{array}{l}\text { Senior BSN students. } \\
54 \% \text { nursing assistant } \\
8 \% \text { licensed vocational. } \\
\text { Associate degree students. }\end{array}$ & $76.6 \%$ white. \\
\hline $\begin{array}{l}\text { 7. Smith (2006) } \\
\text { USA }\end{array}$ & $\begin{array}{l}87 \% \text { female, } \\
12 \% \text { male. }\end{array}$ & $\begin{array}{l}\text { Mean age } 16.6 \text { years. } \\
\text { Response rate not reported. }\end{array}$ & $\begin{array}{l}\text { 39.1\% certified nurse’s aides. } \\
\text { 2.2\% licensed vocational. } \\
\text { 15.1\% nurse extern. } \\
\text { 43.7\% no clinical experience. } \\
60 \% \text { BSN students. } \\
\text { 37\% Associate degree students. }\end{array}$ & $\begin{array}{l}\text { 76\% white. } \\
\text { 6\% Afro-American. } \\
\text { 6\% Hispanic } \\
\text { 5\% Asian American/ } \\
\text { Pacific Islander. } \\
\text { 2\% Native American. }\end{array}$ \\
\hline $\begin{array}{l}\text { 8. Smith (2007) } \\
\text { USA }\end{array}$ & $\begin{array}{l}91.1 \% \text { female. } \\
8.9 \% \text { male. }\end{array}$ & $\begin{array}{l}\text { Mean age } 25.6 \text { years. } \\
\text { Response rate } 7.9 \% \text {. }\end{array}$ & $\begin{array}{l}79 \text { RNs. } \\
9 \text { between } 1 \text { and } 4 \text { years. } \\
12 \text { between } 5 \text { and } 10 \text { years } \\
10 \text { between } 11 \text { and } 15 \text { years. } \\
8 \text { between } 16 \text { and } 20 \text { years. } \\
10 \text { between } 21 \text { and } 25 \text { years. } \\
30 \text { over } 25 \text { years. }\end{array}$ & $\begin{array}{l}\text { 22.8\% white } \\
34.2 \text { Afro-American } \\
\text { 6.3\% Hispanic } \\
27.8 \% \text { Asian-American } \\
1.3 \% \text { Native American } \\
\text { 1\% Other }\end{array}$ \\
\hline
\end{tabular}

RN = Registered Nurses; BSN = students enrolled in a Bachelor of Science in Nursing; AN = Auxiliary Nurse. 
Table 3. Results from the thematic analysis.

\begin{tabular}{lll}
\hline Sub-themes & Themes & Main theme \\
$\begin{array}{l}\text { Sensing physical sensations and spiritual connections } \\
\text { with patients }\end{array}$ & $\begin{array}{l}\text { A sudden emotional awareness and } \\
\text { reflection }\end{array}$ & $\begin{array}{l}\text { Sensing an unconscious and conscious } \\
\text { state of mind }\end{array}$ \\
$\begin{array}{l}\text { Worrying and reassuring feelings } \\
\begin{array}{l}\text { Willingness to act on personal, interpersonal, and } \\
\text { clinical experiences }\end{array}\end{array}$ & $\begin{array}{l}\text { Arousal of cognitive conscious thought } \\
\text { processes. }\end{array}$ \\
$\begin{array}{l}\text { The influence of maturity and social support in clinical } \\
\text { decision-making }\end{array}$
\end{tabular}

ings were described as being relieved, calm, and confident when the patient is stable, and knowing that all will be well [29]. The highest percentage of participants opted for the response alternatives "sometimes" and "often” for "bad feelings" and "often” and "always” for "reassuring feelings” [27]. The highest intuition scores were noted in the categories "spiritual connections" and "reassuring feelings". There were no statistically significant differences in the intuition levels of the nursing staff related to specialty or work experience. However, the categories into which the questionnaire is divided showed a positive correlation between them [27].

\subsubsection{Arousal of Cognitive Conscious Thought Processes}

The mind can integrate memory and different patterns of recognition without cognitive directions. If intuition was not developed, the nurses used cognitive ability rationally through a conscious integration of memory and patterns of recognition in order to reach a decision. Such rational expertize and decisions require conscious, logical thought processes.

1) Willingness to Act on Personal, Interpersonal, and Clinical Experiences

Some results revealed that nurses must be willing to act on personal and interpersonal experiences in nursing practice, while other results demonstrated an important link between the number of years of nursing expertise and clinical experiences in the nursing field [24] [26] [29] highlighted the fact that nursing students experience intuition in a similar fashion to qualified nurses if they have intuitive experiences to reflect on. Nursing students reported positive experiences with intuition when they had worked in an environment that was supportive of intuition [29]. Practicing nurses tend to have a specialty and are often more confident in providing care and reporting their intuitive feelings because of their experiences [29]. The results revealed different reasons why the factors were clearer in a sample of experienced nurses [30]. Nevertheless, when the intuition instrument was tested in nursing students it was found that they also experienced intuitive feelings when caring for patients [30]. The results indicated the effect of experience on intuition, both in the domain of experience and in general, although as expected, nurses with greater experience preferred using their intuition in the field compared to those with little or no clinical experience [26]. Generally, the preference for intuition increased with the level of nursing experience. Nursing students scored lower than all other groups and were less willing to act on intuition than nurses with more than four years of experience. Nurses with up to four years of experience scored lower than nurses with 12 - 25 years of experience. Very experienced nurses have greater confidence in their intuitive decisions [26]. Cork [24] stated that the level of education and certification did not seem to be related to years of experience or the self-rated level of expertise in nurses with more than 16 years of nursing experience. Nursing intuition was described as a willingness to act on personal and clinical experiences. Experiences were defined as the nurses' overall knowledge, including their personal, as well as clinical experiences.

2) The Influence of Maturity and Social Support in Clinical Decision-Making

The findings revealed that novice nurses also used intuition if they were more mature, had experience of been hospitalized for serious health problems, and needed social support from family and friends [28]. Novice nurses were willing to use intuition to guide their decisions about patient care. This finding was explained by personal and interpersonal experiences, rather than clinical experiences in either nursing school or the workplace [28]. Clinical experiences and number of months in nusing practice were not significantly associated with novice nurses' use of intuition during their first year after nursing school. Thus the use of intuition was unrelated to a high grade point average because it represents a different cognitive skill to the more analytical types of information measured by traditional methods. Bright students may not be intuitive, while students who are academically average may be intuitive [28]. 


\section{Discussion}

The aim of this systematic review was to illuminate intuition in clinical nursing. The review question was: What is described as intuition in clinical nursing? The results revealed one main theme: Sensing an unconscious and conscious state of mind and two themes: A sudden emotional awareness and reflection, and arousal of conscious thought processes. The discussion will be a reflection on different aspects of the results of this review, as well as on research and theories about intuition.

Sensing an unconscious and conscious state of mind. A decade ago intuition was described as being associated with non-rational forms of knowledge [34]. One needed to hold fast to one's beliefs and create relationships that could enhance one's intuitiveness. The unconscious could be seen a supplement to consciousness. When the notion of consciousness decreased, the notion of the unconscious increased, as a large proportion of mental activity takes place automatically and is often presented and explained via dreams, delusions, passions, inspirations, and even religious experience [34]. Thus the unconscious seems to have become an ontology by which individuals explain and attribute some meaning to their lives. According to White [35], referring to the unconscious as a part of consciousness might be a misnomer. If one attempts to understand unconscious ideas they are more likely to be seen as contradictions with no relationship to consciousness. It may thus be impossible to clearly define or refer to unconsciousness.

Consciousness can be seen as a response to one's surroundings and thus a sudden emotional awareness and reflection. By observing another human being, one can sense whether she/he is aware of the same thing, without being quite conscious of one's own psychic state. Consciousness can be seen as lying at the root of all knowledge, while intuitive thinking can increase learning and create clinical practice. Concentration and reflection can generate an emotional awareness that can motivate a nurse to further explore the clinical situation. Olsson and Adolfsson [20] stated that intuitive thinking and the ability to use it in a given situation can be proportional to the level of the informants' experiences. When employed in this way, intuitive thinking can be a sixth sense, as well as a cognitive skill for developing clinical action and a valid form of knowledge [16] [18]. Intuition has been studied broadly in the social sciences, but sparse research exists on the experiences of nurses who use intuition in their decision-making processes. The lack of research on intuition in mental health nursing is striking, as neglecting expert intuition can lead to suicide and death [18]. Several decades ago Young [36] stated that intuitive feeling cannot be taught without actually having the necessary experiences to provoke the same feelings in the clinical situation. If this is true, nurses need to be trained how to make decisions based upon intuitive knowledge and subjective facts. Intuition can involve an immediate understanding without logical grounds, allowing one to make decisions that can be difficult to explain afterwards, irrespective of the fact that one acted correctly [37]. However, one cannot trust intuition blindly because in some cases the decision can be wrong. Occasionally prior experiences can be helpful when drawing on intuition in clinical practice, as personal maturity strengthens professional expertise [28]. Personal and work experience over time increases expert knowledge, which informs the meaning and use of intuition [38]. It seems as intuitive feelings can be taught without having the experience necessary to provoke these feelings.

A relationship to a spiritual source, to co-workers and to patients seems to be a key to intuition. One need not solely focus on rational forms of knowledge, but open the doors for research on intuition [17]. A workplace culture where one can learn from earlier decisions in order to develop expert intuition may be necessary. In mental health, a sense of coherence in relation to the patient's situation is necessary, where the nurse's contribution can consist of simply "being there", which enhances her/his emotional awareness [39]. In certain circumstances intuitiveness may be a means of increasing understanding of the patient's emotional pain and opening new ways that improve clinical nursing [40].

Intuition in clinical nursing is described as worrying and reassuring feelings by Smith [30] and Rovithis et al. [27]. Nurses seem to provide reassurance, even if students did not experience it [30]. Worrying and reassuring feelings, as well as spiritual relationships with patients can facilitate the early detection of problems.

Conscious thought processes seem to be aroused by cognitive consciousness and exploring background understanding. Cognitive consciousness can be seen as an "intuition” about one's own state of mind or as a subjective awareness of some aspects of an ongoing mental process. Such understanding cannot function without a rationale [12] and may be related to the neuroscientific evidence [1] [2] that seems to enable comprehension of how the emotional center functions. Different response patterns may be sent to the cognitive consciousness by the nurse, a process by which wisdom appears to be used intuitively [41]. Such arousal appears to be impossible 
without intuitive information. Clinicians often described this arousal of consciousness thought processes and awareness [10] [17]. A relational form of knowledge can be useful in clinical nursing. There are many examples of the significance of relationships with supervisors, patients, doctors, and members of the healthcare team based on rational and non-rational forms of knowledge, as well as previous life experiences [17] [28]. Some clinicians need time to discover their intuition when involved in life-threatening situations and have to put themselves into a certain space such as ([42], p. 41).

One can be more confident in providing care when intuitive feelings are based on a willingness to act on personal, interpersonal, and clinical experiences. The results of this review, as well as those from qualitative studies [20] [37] provided some support for Benner's [38] finding that intuition can increase with experience and expertise. However, intuition should be combined with objective, empirical evidence when evaluating a patient's condition and planning her/his care.

Several factors based on maturity and social support in clinical decision making influence the use of intuition, which can be explained by personal and interpersonal rather than professional experiences. A nurse with a history of health problems and hospitalization may be better able to empathize with patients and share her/his experiences to guide them through the hospitalization situation [28]. The relevance of gender in terms of an anatomical and physiological structural predisposition and social construction seems important when considering the use of intuition in clinical nursing [43]. Do women possess greater intuitive ability than the male staff to who they report their fears and concerns? No evidence of this was found in any of the included studies, despite the fact that most of the participants were women (Table 2). Clinical practice is far from being unique to nursing and is not female dominated. Male and female nurses can have high or low self-esteem, be religious or non-religious, and use intuition differently to provide patient care as shown in one of the included studies [28]. Research can cast doubt on the reality of a barrier between 'hard' and 'soft' science by declaring that intuitive thinking cannot be a foundation for the decision to conduct controlled laboratory trials [44]. Another perspective is that of the social and political power struggle between the sexes, or perhaps intuition in nursing has more to do with patriarchy and the reluctance to develop a female dominated profession [10] [43].

Intuition may function as a holistic, complex, experience, and knowledge-based approach to decision-making. For this reason, the role of "irrational" aspects in decision-making and how they can be understood as components of credible practice must be discussed in clinical nursing [19]. Experience can be a reference point for checking whether there are other suggestions based on intuition that ignore clinical guidelines [19]. In order to strengthen autonomous decision-making processes it might be necessary to start a discourse about the topic based on an understanding of everyday events [19]. As a profession, nursing has relied on relational knowledge and the ability to relate to others, as supportive relationships facilitate greater use of intuition in clinical decisions.

\subsection{Implications for Clinical Practice and Research}

Nurses seem to use intuition in all phases of clinical practice and in some cases found ways to promote a balance between intuition, science, and other forms of knowledge. Clinical nursing is often complex because of rapid patient turnover, the development of new technology, and fewer experienced nurses at the bedside due to a shortage of staff. Intuition can help to change practice by promoting self-reflection and increasing understanding of how feelings influence decision-making in clinical nursing [26] [27]. Pretz and Folse ([26], p. 2887) question whether intuitive nurses are more accurate in predicting patient outcomes. Nursing intuition can be successful in clinical practice if one can develop a sensitivity that includes spiritual cues as a key to understanding the patient's illness. Less experienced nurses need more knowledge about how to trust their intuitions. Benner ([45], p. 210) stated that "intuition constitutes a significant part of the everyday practice of expert nurses". Although experience leads to increased self-confidence in intuition, this may not be related to improved accuracy of judgement. Nurses often meet patients in vulnerable situations, which give them the power to influence how these patients experience their lives. When caring for patients who are in a position of weakness it is imperative to employ intuitive knowledge and be aware of one's power in order to avoid misusing it. Nursing experience is described as playing a major role in the use of intuition.

New research instruments are required to measure intuition, and research needs to be carried out on intuition in the areas of physical and mental health in communities and hospitals in different countries so that the results can be compared. Building nursing research depends on applying knowledge from rational and intuitive cogni- 
tive cases [46]. The limited body of knowledge on nursing intuition indicates a need for more studies that explore the nature and use of intuition on every level and in every clinical nursing setting.

\subsection{Methodological Limitations of the Included Studies}

A problem in the included studies is that the limitations described differ. Three of the studies have a cross-sectional design [24] [25] [30]. Such studies measure data at one point in time (i.e., data are collected on only one occasion rather than with the same participants at several points in time) [47]. Cross-sectional analytic studies use inferential statistics to indicate a causal relationship between two or more variables of interest [45]. Risk of bias can be related to the fact that none of the three cross-sectional studies described problems with causality, nor did they have a control group, which makes it difficult to draw conclusions about whether the effects were caused by the intervention or by other factors. Three studies used factor analysis to test, revise, and administer the intuition instrument [29]-[31]. Two of the included studies employed correlational analysis [25] [37], and one used a cohort analysis [26]. The use of many different statistical analyses can decrease the validity and reliability of the review as the included studies differ a great deal in terms of aim and intention, which can increase the risk of bias [47]. Another limitation might be that the authors were unable to determine a causal relationship between the variables because of the lack of manipulation, control, and randomization. Failure to mention validity and reliability as a limitation is a serious mistake that increased bias in one of these studies [24]. The studies varied in terms of the description of limitations. Three of the included cross-sectional studies [25] [26] [30] have no randomization of their sampling, which weakens the ability to generalize the results. According to Shadish et al. [48], self-reports can increase the likelihood of response bias. In three studies it was stated that the measures were self-report in nature [25] [26] [29]. Pretz \& Folse [26] mentioned that the measures do not necessarily reflect the use of intuition in decision-making, while Smith et al. [29] pointed out that the participants may have answered the scale items in a way that they thought would please the investigator.

Only one study described the fact that the sample comprised a majority of white women as a limitation [28]. The sample in seven studies is dominated by women (Table 2) and white people [29], but no information was provided about how this could be a limitation in terms of generalization. In one study the sample was described as predominantly Afro-American [30]. Four studies did not report ethnicity and one made no mention of gender (Table 2).

In one study it was stated that the characteristics of the respondents matched the general characteristics of members of the nursing profession in terms of age, sex, nursing education, and ethnicity [29]. In another study it was pointed out that the limitations included a low response rate and the absence of demographic questions related to specialty experience [30].

Four studies have a relatively small sample size from 8 to 175 [24] [26] [27] [30] (Table 1), but selection bias was not described as a limitation in any of them. Cork [24] did mention that the small sample size is a limitation, but Smith [31] did not consider it a problem. In one study the use of only a single group was not considered a limitation [27]. Using one group was described in two studies [24] [26] (Table 1), but none of these authors mentioned being affected by the history threat that could decrease the validity of their study [48].

\subsection{Limitations of This Review}

Bias is defined as leading to distortion in the results and threatening validity [23], which might be a limitation in this review. The search strategy can also be a limitation in a review, as the possibility of excluding relevant studies is ever present. The number of studies published is increasing and new evidence could change the relevance of a review in terms of dependability, which refers to the stability (reliability) of data and conditions over time [23]. In addition, a qualitative analysis can be a limitation when exploring the data as the interpretation of the results is subjective, which weakens the validity and reliability. As the studies included different aims, research questions, and statistical analyses, a meta-synthesis would be the best way to review them [49].

Six studies were from the USA, one from Greece, and one from Australia (Table 1). As the cultures in these countries might differ from those in other areas, further studies in other parts of the world are recommended. Quantitative studies also need to strengthen their design, validity, and reliability.

\section{Conclusions}

Leadership and management can initiate new discussions about the use of intuition in clinical nursing. 
The theories pertaining to intuition need to be evaluated if it is to continue as a legitimate way of processing information and making decisions about patient care. Greater use of intuition can provide students with learning experiences and teach them to be more sensitive to patients' wishes. This can be facilitated by the use of simulation in the hospital, the community, the nursing laboratory, and in the classroom. A supportive environment and problems in students' lives may increase their sensitivity to patient needs. The development of team-building and networks may help to enhance intuition in clinical practice. Healthcare leadership and management need to establish supervisor and mentor programs for new graduates to develop the use of intuition to guide decisions about patient care.

\section{Acknowledgements}

We want to thank Monique Federsel for reviewing the English language.

\section{Competing Interest}

The author's declare that there are no conflicts of interest.

\section{Contributors}

The study was designed by A.L.H. A.L.H. coordinated the research. All authors participated in the data analysis. The authors contributed intellectually to the writing of the manuscript. The authors read and approved the final manuscript.

\section{References}

[1] Damasio, A.R. (2000) The Feeling of What Happens: Body and Emotion in the Making of Consciousness. Vintage, London.

[2] Damasio, A.R., Damasio, H. and Christen, Y. (1996) The Neurobiology of Decision Making. Springer Verlag, Berlin. http://dx.doi.org/10.1007/978-3-642-79928-0

[3] Roberts, A.C., Robbins, T.W. and Weiskrantz, L. (1998) The Prefontal Cortex Executive and Cognitive Functions. University Press, Oxford.

[4] Panksepp, J. (1998) Affective Neuroscience. The Foundations of Human and Animal Emotions. Oxford University Press, Oxford.

[5] Shirley, D.A. and Langan-Fox, J. (1996) Intuition: A Review of the Literature. Pscychological Reports, 79, 563-584. http://dx.doi.org/10.2466/pr0.1996.79.2.563

[6] Henley, R. (1999) Distinguishing Insight from Intuition. Journal of Consciousness Studies, 6, 287-290.

[7] McCraty, M., Atkinson, M. and Bradley, R.T. (2004) Electrophysiological Evidence of Intuition: Part 1. The Surprising Role of the Heart. Journal of Alternative Complementary Medicine, 20, 133-143. http://dx.doi.org/10.1089/107555304322849057

[8] McCraty, R., Atkinson, M. and Bradley, R.T. (2004) Electrophysiological Evidence of Intuition: Part 2. A System-Wide Process? Journal of Alternative and Complementary Medicine, 20, 325-336. http://dx.doi.org/10.1089/107555304323062310

[9] Appleton, J.V. and Cowley, S. (2003) Valuing Professional Judgement in Health Visiting Practice, Community Practice, 76, 215-220.

[10] McKinnon, J. (2005) Feeling and Knowing: Neural Scientific Perspectives on Intuitive Practice. Nursing Standard, 20, 41-46. http://dx.doi.org/10.7748/ns2005.09.20.1.41.c3953

[11] Carper, B.A. (1978) Fundamental Patterns of Knowing in Nursing. Advances in Nursing Science, 1, 13-24. http://dx.doi.org/10.1097/00012272-197810000-00004

[12] Benner, P. and Tanner, C. (1987) Clinical Judgment: How Expert Nurses Use Intuition. The American Journal of Nursing, 87, 23-31. http://dx.doi.org/10.2307/3470396

[13] King, I. and Appleton, J.A. (1997) Intuition: A Critical Review of the Research and Rhetoric. Journal of Advanced Nursing, 37, 194-202. http://dx.doi.org/10.1046/j.1365-2648.1997.1997026194.x

[14] Gobet, F. and Chassy, P. (2008) Towards an Alternative to Benner's Theory of Expert Intuition in Nursing: A Discussion Paper. International Journal of Nursing Studies, 45, 129-139. http://dx.doi.org/10.1016/j.ijnurstu.2007.01.005

[15] Rew, L. and Barrow, E.M. (2007) State of the science: Intuition in nursing, a generation of studying the phenomenon. 
Advances in Nursing Science, 30, E15-F25. http://dx.doi.org/10.1097/00012272-200701000-00011

[16] Robert, R.R., Tilley, D.S. and Petersen, S. (2014) A Power in Clinical Nursing Practice: Concept Analysis on Nursing Intuition. Medsurg Nursing: Official Journal of the Academy of Medical-Surgical Nurses, 23, 343-349.

[17] Ruth-Sahd, L.A. and Tisdell, E.J. (2007) The Meaning and Use of Intuition in Novice Nurses: A Phenomenological Study. Adult Education Quarterly, 57, 115-140. http://dx.doi.org/10.1177/0741713606295755

[18] Lyneham, J., Parkinson, C. and Denholm, C. (2008) Intuition in Emergency Nursing: A Phenomenological Study. International Journal of Nursing Practice, 14, 101-108. http://dx.doi.org/10.1111/j.1440-172X.2008.00672.x

[19] Traynor, M., Boland, M. and Buus, N. (2010) Autonomy, Evidence and Intuition: Nurses and Decision-Making. Journal of Advanced Nursing, 66, 1584-1591. http://dx.doi.org/10.1111/j.1365-2648.2010.05317.x

[20] Olsson, A. and Adolfsson, A. (2011) Midwife’s Experiences of Using Intuition as a Motivating Element in Conveying Assurance and Care. Health, 3, 453-461. http://dx.doi.org/10.4236/health.2011.37075

[21] Aveyard, H. (2014) Doing a Literature Review in Health and Social Care, A Practical Guide. 3rd Edition, Open University Press, London.

[22] Liberati, A., Altman, D.G., Tetzlaff, J., Mulrow, C., Götzsche, P., Ionnidis, J.P., Clarke, M., Devereaux, P.J., Kleijnen, D. and Moher, D. (2009) The PRISMA Statement for Reporting Systematic Reviews and Meta-Analyses of Studies that Evaluate Healthcare Interventions: Explanation and Elaboration. BMJ, 339, b2700. http://dx.doi.org/10.1136/bmj.b2700

[23] Polit, D.F. and Beck, C.T. (2012) Nursing Research: Generating and Assessing Evidence for Nursing Practice. Wolters Kluwer/Lippincott Williams \& Wilkins, Philadelphia.

[24] Cork, L.L. (2014) Nursing Intuition as an Assessment Tool in Predicting Severity of Injury in Trauma Patients. Journal of Trauma Nursing, 21, 244-252. http://dx.doi.org/10.1097/JTN.0000000000000072

[25] Farr-Wharton, R., Brunetto, Y. and Shacklock, K. (2011) The Impact of Intuition and Supervisor-Nurse Relationships on Empowerment and Affective Commitment by Generation. Journal of Advanced Nursing, 68, 1391-1401. http://dx.doi.org/10.1111/j.1365-2648.2011.05852.x

[26] Pretz, J.E. and Folse, V.N. (2011) Nursing Experience and Preference for Intuition in Decision Making. Journal of Clinical Nursing, 20, 2878-2889. http://dx.doi.org/10.1111/j.1365-2702.2011.03705.x

[27] Rovithis, M., Stavropoulou, A., Katsigaraki, N., Sotiropoulos, M., Sfigkaki, D., Linardakis, M. and Rikos, N. (2015) Evaluation of Intuition Levels in Nursing Staff. Health Sciences Journal, 9, 1-7.

[28] Ruth-Sahd, L.A. and Hendy, H.M. (2005) Predictors of Novice Nurses' Use of Intuition to Guide Patient Care Decisions. Journal of Nursing Education, 44, 450-458.

[29] Smith, A.J., Thurkettle, M.A. and dela Crutz, F.A. (2004) Use of Intuition by Nursing Students: Instrument Development and Testing. Journal of Advanced Nursing, 47, 614-622. http://dx.doi.org/10.1111/j.1365-2648.2004.03149.x

[30] Smith, A. (2007) Measuring the Use of Intuition by Registered Nurses in Clinical Practice. Nursing Standard, 21, 3541. http://dx.doi.org/10.7748/ns2007.08.21.47.35.c4591

[31] Smith, A.J. (2006) Continued Psychometric Evaluation of an Intuition Instrument for Nursing Students. Journal of Holistic Nursing, 24, 82-89. http://dx.doi.org/10.1177/0898010105280114

[32] Pope, C., Mays, N. and Popay, J. (2007) Synthesizing Qualitative and Quantitative Health Evidence: A Guide to Methods. McGraw-Hill Open University Press, London.

[33] Holopainen, A., Hakulinen-Viitanen, T. and Tosavainen, T. (2008) Systematic Review-A Method for Nursing Research. Nurse Researcher, 16, 72-83. http://dx.doi.org/10.7748/nr2008.10.16.1.72.c6754

[34] Shamdasani, S. (2005) Unconscious. The Lancet, 365, 1921. http://dx.doi.org/10.1016/s0140-6736(05)66647-0

[35] White, W. (2013) The Unconscious. The Psychoanalytic Review, 100, 57-72.

http://dx.doi.org/10.1521/prev.2013.100.1.57

[36] Holm, A.L. and Severinsson, E. (2011) A Hermeneutic Approach to the Characteristics of Mental Health Nursing Practice. Journal of Psychiatric \& Mental Health Nursing, 18, 843-850. http://dx.doi.org/10.1111/j.1365-2850.2011.01736.x

[37] Young, C.E. (1987) Intuition and Nursing Process. Holistic Nursing Practice, 1, 52-62. http://dx.doi.org/10.1097/00004650-198705000-00010

[38] Berg, M., Lundgren, I., Hermansson, E. and Wahlberg, V. (1996) Women's Experience of the Encounter with the Midwife during Childbirth. Midwifery, 12, 11-15. http://dx.doi.org/10.1016/S0266-6138(96)90033-9

[39] Benner, P.E. (2001) From Novice to Expert: Excellence and Power in Clinical Nursing Practice. Prentice Hall, Upper Saddle River.

[40] Holm, A.L., Lyberg, A., Lassenius, E. and Severinsson, E. (2013) Older Persons’ Lived Experiences of Depression and 
Self-Management. Issues in Mental Health Nursing, 34, 757-764. http://dx.doi.org/10.3109/01612840.2013.809829

[41] Holm, A.L. (2009) The Meaning of Emotional Pain. Analytic Interpretative Research on Women's Experiences of Mental Health Problems. Doctoral Thesis, the Department of Health Studies, Faculty of Social Sciences, University of Stavanger, Stavanger.

[42] Gupta, R., Koscik, T.R., Bechara, A. and Tranel D. (2011) The Amygdala and Decision-Making. Neuropsychologia, 49, 760-766. http://dx.doi.org/10.1016/j.neuropsychologia.2010.09.029

[43] Daly, B.J. (2001) Learning and Professional Practice: A Study of Four Professions. Adult Education Quarterly, 52, 39-54. http://dx.doi.org/10.1177/074171360105200104

[44] Code, L. (1991) What Can She Know? Feminist Theory and the Construction of Knowledge. Cornell University Press, Ithaca.

[45] Klein, L. (2001) Rigour and Intuition in Professional Life. Ergonomics, 44, 579-587. http://dx.doi.org/10.1080/00140130110034462

[46] Benner, P.C., Tanner, C. and Chesla, C. (2009) Clinical Judgment: How Expert Nurses Use Intuition. The American Journal of Nursing, 87, 23-31.

[47] Rew, L. (2000) Acknowledging Intuition in Clinical Decision-Making. Journal of Holistic Nursing, 18, 94-108. http://dx.doi.org/10.1177/089801010001800202

[48] Schneider, Z., Whitehead, D., Elliott, D.G., Lobiondo-Wood, G. and Haber, J. (2007) Nursing \& Midwifery Research: Methods and Appraisal for Evidence-Based Practice. Mosby, Maryland Heights.

[49] Jesson, J., Matheson, L. and Lacey, F. (2011) Doing Your Literature Review: Traditional and Systematic Techniques. Sage, London. 